\title{
Water-borne hyphomycetes in tree canopies of Kaiga (Western Ghats), India
}

\author{
NAGA M. SUDHEEP and KANDIKERE R. SRIDHAR
}

Department of Biosciences, Mangalore University

Mangalagangotri, Mangalore IN-574-199, India, sirikr@yahoo.com

Sudheep N. M., Sridhar K. R.: Water-borne hyphomycetes in tree canopies of Kaiga (Western Ghats), India. Acta Mycol. 45 (2): 185-195, 2010.

The canopy samples such as trapped leaf litter, trapped sediment (during summer), stemflow and throughfall (during monsoon) from five common riparian tree species (Artocarpus heterophyllus, Cassia fistula, Ficus recemosa, Syzygium caryophyllatum and Xylia xylocarpa) in Kaiga forest stand of the Western Ghats of southwest India were evaluated for the occurrence of water-borne hyphomycetes. Partially decomposed trapped leaf litter was incubated in bubble chambers followed by filtration to assess conidial output. Sediments accumulated in tree holes or junction of branches were shaken with sterile leaf disks in distilled water followed by incubation of leaf disks in bubble chamber and filtration to find out colonized fungi. Stemflow and throughfall samples were filtered directly to collect free conidia. From five canopy niches, a total of 29 water-borne hyphomycetes were recovered. The species richness was higher in stemflow and throughfall than trapped leaf litter and sediments (14-16 vs. 6-10 species). Although sediments of Syzygium caryophyllatum were acidic (5.1), the conidial output was higher than other tree species. Stemflow and throughfall of Xylea xylocarpa even though alkaline (8.5-8.7) showed higher species richness (6-12 species) as well as conidial load than rest of the tree species. Flagellospora curvula and Triscelophorus acuminatus were common in trapped leaf litter and sediments respectively, while conidia of Anguillospora crassa and A. longissima were frequent in stemflow and throughfall. Diversity of water-borne hyphomycetes was highest in throughfall of Xylea xylocarpa followed by throughfall of Ficus recemosa. Our study reconfirms the occurrence and survival of diverse water-borne hyphomycetes in different niches of riparian tree canopies of the Western Ghats during wet and dry regimes and predicts their possible role in canopy as saprophytes, endophytes and alternation of life cycle between canopy and aquatic habitats.

Key words: water-borne hyphomycetes, diversity, conidia, canopy, leaf litter, sediment, stemflow, throughfall 


\section{INTRODUCTION}

Forest canopies are endowed with a mosaic of flora, fauna and microbes (Nadkarni et al. 2001). Tropical canopy of Ecuador trap about 200-300 kg dry mass of litter per hectare consisting of at least 500-600 m of rhizomorphs (e.g., Marasmius spp.) per $\mathrm{kg}$ litter, which is equivalent to approximately $180 \mathrm{~km}$ per hectare (Hedger 1990). A rough estimate of microfungal biomass in twigs and needle surfaces of old-growth Douglas fir forest canopies was up to $450 \mathrm{~kg} / \mathrm{ha} / \mathrm{yr}$ (Carroll et al. 1980). Thus, canopies provide a wide variety of niches and accommodate a broad group of fungi (e.g., phylloplane fungi, endophytes, pathogens, lignicolous fungi) (Lodge, Cantrell 1995; Stone et al. 1996; Shaw 2004). Besides these, water-borne fungi (aquatic and aero-aquatic hyphomycetes) are also known from canopies. They have been reported from the epiphytes, tree holes, trapped leaf litter, stemflow, throughfall and other niches of canopy in temperate and tropical regions (e.g., Ando, Tubaki 1984; Czeczuga, Orłowska 1998a, 1999; Gönczöl, Révay 2006; Sridhar et al. 2006; Karamchand, Sridhar 2008, Sridhar 2009; Sridhar, Karamchand 2009). Typical water-borne hyphomycetes are also endophytic in needles of black spruce (Picea mariana) of a mixed woody forest in Canada (Sokolski et al. 2006). Tree holes (formed due to decomposition of branches) and junctions of branches act as receptacles for deposition of water, sediment, leaf litter and other canopy debirs, which constitute ideal substratum for colonization and survival of water-borne hyphomycetes. Water from mist or rain flowing along the trunks (stemflow) and dripping from foliage (throughfall) are also major sources of conidia of water-borne hyphomycetes. About 33 species of fungi encompassing many water-borne hyphomycetes have been reported in rainwater dripping through building roofs in Poland and predicted their survival due to accumulation of sediments on undulating roof surfaces (Czeczuga, Orłowska 1997). Floral honey and honeydew excreted by the aphids in canopies are also serve as niches for fungi (Magyar et al. 2005). So far, about 125 species of water-borne hyphomycetes have been reported from the tree canopies (Sridhar 2009; Karamchand, Sridhar 2009; Sridhar, Karamchand 2009).

The Western Ghats of India $\left(8^{\circ} 20^{\prime}-20^{\circ} 40^{\prime} \mathrm{N}\right.$ and $\left.73^{\circ}-77^{\circ} \mathrm{E}\right)$ as a hotspot of biodiversity endowed with moist deciduous and montane rain forests at an elevation up to $2000 \mathrm{~m}$ asl. The vegetation mainly consists of scrub jungle, grasslands, moist to dry deciduous forests, tropical evergreen forests and sholas. Water-borne hyphomycetes have been explored from streams and rivers of coastal, mid-altitude (foothill) and mountain regions of the Western Ghats (e.g., Sridhar, Kaveriappa 1989; Chandrashekar et al. 1990; Sridhar et al. 1992; Raviraja et al. 1998; Rajashekhar, Kaveriappa 2003). In view of limited studies on water-borne hyphomycetes of tree canopies in tropics (Sridhar et al. 2006; Karamchand, Sridhar 2008; Sridhar, Karamchand 2009), the present investigation aims at exploring their assemblage and diversity in canopies of selected tree species during summer and monsoon seasons in Kaiga forest stand located at the Western Ghats of southwest India. 


\section{MATERIALS AND METHODS}

The location selected for study is situated adjacent to the River Kali near Kaiga nuclear power station of the southwest India ( $\sim 35 \mathrm{~km}$ east of the Karwar City; $\sim 55-70$ $\mathrm{m}$ asl; $14^{\circ} 50^{\prime}-14^{\circ} 51^{\prime} \mathrm{N}, 74^{\circ} 26^{\prime} \mathrm{E}$ ). Three trees each of five species (Artocarpus heterophyllus Lam., Cassia fistula L., Ficus recemosa Linn., Syzygium caryophyllatum (L.) Alston and Xylia xylocarpa Roxb. Taub.) distributed in an area of $300 \mathrm{~m}^{2}$ were chosen for study. The canopies of trees selected were free from interference of other trees. During April 30, 2009 (summer), partially decomposed trapped leaf litter at the tree holes or junctions of branches were sampled (the mean rainfall, temperature and humidity during April 2009 in Kaiga forest was $0.7 \mathrm{~mm}, 30.8^{\circ} \mathrm{C}$ and $71.1 \%$ respectively). They were transported to the laboratory and rinsed in distilled water to remove adhered debris. Small segments (5-8) weighing about 100-250 mg dry mass were aerated up to $48 \mathrm{~h}$ in $250 \mathrm{ml}$ Erlenmeyer flasks containing $150 \mathrm{ml}$ of sterile distilled water (bubble chamber) at laboratory temperature $\left(28 \pm 2^{\circ} \mathrm{C}\right)$. Aerated water was filtered through Millipore filters ( $5 \mu \mathrm{m}$; diam., $47 \mathrm{~mm}$ ) to trap released conidia of water-borne hyphomycetes. The filters were stained with $0.1 \%$ aniline blue in lactophenol. Each stained filter was cut in to half, mounted on a microscope slide with a few drops of lactic acid for screening conidia (Nikon OPTIPHOT, Japan: $20 \times$, $40 \times, 100 \times)$ and they were identified based on conidial morphology using primary literature and monographs (Ingold 1975a; Nawawi 1985; Marvanová 1997; Gulis et al. 2005). Sediments accumulated at the tree holes or junctions of branches sampled during April 30, 2009 were assessed for the presence of water-borne hyphomycetes by indirect method (Sridhar et al. 2008). Five pre-weighed sediment samples (200$300 \mathrm{mg}$ dry mass) were used (parallel samples were weighed before and after drying at $100^{\circ} \mathrm{C}$ for $24 \mathrm{~h}$ to convert wet to dry mass). Each sediment sample was transferred to $250 \mathrm{ml}$ Erlenmeyer flask containing $150 \mathrm{ml}$ sterile distilled water with 5 sterile banyan leaf (Ficus benghalensis L.) disks (1.5 cm diam.). The flasks were incubated on a rotary shaker for 14 days $\left(150 \mathrm{rpm}, 28 \pm 2^{\circ} \mathrm{C}\right)$. The leaf disks were harvested, rinsed in distilled water to eliminate sediments and incubated in bubble chambers to stimulate production of conidia from colonized fungi and assessed further as described above.

Stemflow and throughfall of each tree were collected during July 30, 2009 (monsoon) (mean rainfall, temperature and humidity during July 2009 in Kaiga forest was $1767 \mathrm{~mm}, 26.9^{\circ} \mathrm{C}$ and $98.2 \%$ respectively). Shortly after the beginning of the rainy period (20-30 $\mathrm{min}$ ), about $200 \mathrm{ml}$ of water draining through the main stem was collected in sterile polythene bags and transferred to sterile glass bottles. A clean polythene sheet $\left(2 \mathrm{~m}^{2}\right)$ was spread below the canopy of each tree $(\sim 1 \mathrm{~m}$ above ground and $\sim 3 \mathrm{~m}$ away from tree base), up to $200 \mathrm{ml}$ of water dripping through each canopy was sampled and transferred to sterile glass bottles. Within $30 \mathrm{~min}$ of sampling, aliquots $(25 \mathrm{ml})$ of stemflow and throughfall were separately filtered through Millipore filters to assess the free conidia of water-borne hyphomycetes.

Sediment moisture (gravimetric), $\mathrm{pH}$ and conductivity (1:2 dilution with distilled water) were assessed using water analysis kit (Water Analyzer 371, Systronics, Gujarat, India). Similarly, temperature, $\mathrm{pH}$ and conductivity of stemflow and throughfall were assessed at the sampling site. Parts of stemflow and throughfall samples 
were fixed at the site to estimate dissolved oxygen by Winkler's method (APHA 1995).

Based on occurrence of water-borne hyphomycetes in trapped leaf litter, sediment, stemflow and throughfall, Shannon diversity $\left[H^{\prime}=-\sum(p i \times \ln p i)\right]$ (Magurran 1988 ) and Pielou's equitability $\left(J^{\prime}=H^{\prime} \div H^{\prime}\right.$ max) (Pielou 1975) were determined (where $p i$ is the relative abundance of species $i$ and $H^{\prime}$ max is the maximum value of diversity for the number of fungal species present).

\section{RESULTS}

Average moisture content of the trapped leaf litter and sediments of the five tree species was $6.7 \%$ (range 5.5-8.1\%) and 6.6\% (range 5.1-8.1\%) respectively (Tab. 1). The mean temperature of stemflow and throughfall ranged between $24.4^{\circ} \mathrm{C}$ and $25^{\circ} \mathrm{C}$ respectively. The mean $\mathrm{pH}$ of sediment was acidic (6.1) than stemflow (7.1) as well as throughfall (7.6). Sediments of Xylea xylocarpa and Syzygium caryophyllatum were acidic (4.8 and 5.1), while stemflow and throughfall of $X$. xylocarpa were alkaline (8.5 and 8.7$)$. The mean conductivity of sediment was higher $(288 \mu \mathrm{S} / \mathrm{cm})$ than stemflow $(60 \mu \mathrm{S} / \mathrm{cm})$ and throughfall $(61 \mu \mathrm{S} / \mathrm{cm})$. Average dissolved oxygen in stemflow and throughfall was $7.1 \mathrm{mg} / \mathrm{l}$ (range $6.9-7.5 \mathrm{mg} / \mathrm{l})$.

Five canopy niches surveyed yielded a total of 29 species of water-borne hyphomycetes (Tabs 2 and 3). Ten species ranging from 2 (Ficus recemosa) to 6 (Cassia fistula) were recovered from the trapped leaf litter. Six species ranging from 1 (Xylea xylocarpa) to 3 (Artocarpus heterophyllus and F. recemosa) were found in sediment. Conidial output from trapped leaf litter and sediment was highest in Syzygium caryophyllatum and least in X. xylocarpa (Fig. 1). Flagellospora curvula was found in

Table 1

Physicochemical features of canopy samples of five tree species of Kaiga forest assessed for water-borne hyphomycetes ( $\mathrm{n}=3$, mean) (Ah, Artocarpus heterophyllus; Cf, Cassia fistula; $\mathrm{Fr}$,

Ficus recemosa; Sc, Syzygium caryophyllatum; Xx, Xylia xylocarpa)

\begin{tabular}{|c|c|c|c|c|c|c|}
\hline \multirow{2}{*}{ Parameter } & \multicolumn{5}{|c|}{ Tree species } & \multirow{2}{*}{$\begin{array}{l}\text { Mean } \\
(\mathrm{n}=5)\end{array}$} \\
\hline & $\mathrm{Ah}$ & $\mathrm{Cf}$ & Fr & Sc & $\mathrm{Xx}$ & \\
\hline \multicolumn{7}{|c|}{ Trapped leaf litter } \\
\hline Moisture (\%) & 7.5 & 5.6 & 8.1 & 6.9 & 5.5 & 6.7 \\
\hline \multicolumn{7}{|c|}{ Trapped sediment } \\
\hline Moisture (\%) & 8.1 & 6.6 & 5.1 & 7.2 & 5.9 & 6.6 \\
\hline $\mathrm{pH}$ & 6.5 & 7.1 & 7.1 & 5.1 & 4.8 & 6.1 \\
\hline Conductivity $(\mu \mathrm{S} / \mathrm{cm})$ & 302.3 & 75.3 & 276.7 & 554 & 232.7 & 288.2 \\
\hline \multicolumn{7}{|c|}{ Stemflow } \\
\hline Temperature $\left({ }^{\circ} \mathrm{C}\right)$ & 24 & 24.5 & 25 & 25.5 & 26 & 25.0 \\
\hline $\mathrm{pH}$ & 7.3 & 7.5 & 7.3 & 7.2 & 8.5 & 7.6 \\
\hline Conductivity $(\mu \mathrm{S} / \mathrm{cm})$ & 20 & 63.6 & 60.1 & 16.4 & 142 & 60.4 \\
\hline Dissolved oxygen $(\mathrm{mg} / \mathrm{l})$ & 7.5 & 7 & 7 & 7.2 & 7 & 7.1 \\
\hline \multicolumn{7}{|c|}{ Throughfall } \\
\hline Temperature $\left({ }^{\circ} \mathrm{C}\right)$ & 24 & 24 & 25 & 25 & 24 & 24.4 \\
\hline $\mathrm{pH}$ & 7.5 & 7.7 & 7 & 7.3 & 8.7 & 7.6 \\
\hline Conductivity $(\mu \mathrm{S} / \mathrm{cm})$ & 45.1 & 75.7 & 64.6 & 24.5 & 94.4 & 60.9 \\
\hline Dissolved oxygen $(\mathrm{mg} / \mathrm{l})$ & 7 & 7.4 & 6.9 & 7 & 7 & 7.1 \\
\hline
\end{tabular}


Table 2

Percentage contribution of water-borne hyphomycete species to conidial production and diversity in trapped leaf litter and trapped sediment (in parenthesis) of five tree species of Kaiga forest (Ah, Artocarpus heterophyllus; Cf, Cassia fistula; Fr, Ficus recemosa; Sc, Syzygium caryophyllatum; $\mathrm{Xx}$, Xylia xylocarpa)

\begin{tabular}{|l|c|c|c|c|c|}
\hline \multirow{2}{*}{ Taxon } & \multicolumn{5}{c|}{ Tree species } \\
\cline { 2 - 6 } & $\mathrm{Ah}$ & $\mathrm{Cf}$ & $\mathrm{Fr}$ & $\mathrm{Sc}$ & $\mathrm{Xx}$ \\
\hline Flagellospora curvula Ingold & 13.9 & 6.1 & 25.8 & 1.4 & 9.2 \\
\hline Triscelophorus acuminatus Nawawi & & $(71.4)$ & $(95.6)$ & $(96)$ & $(100)$ \\
\hline Lunulospora curvula Ingold & 27.8 & 6.5 & & & 47 \\
& & $(28.6)$ & & & \\
\hline Anguillospora longissima (Sacc. \& P. Syd.) Ingold & 31.1 & & & 1.4 & 5.2 \\
& $(8.1)$ & & & & \\
\hline Flagellospora penicillioides Ingold & 13.9 & 79 & 74.2 & & \\
\hline Cylindrocarpon sp. & 13.2 & & $(0.2)$ & & \\
& $(65.7)$ & & & & \\
\hline Campylospora parvula Kuzuha & & & & 53 & 29.4 \\
\hline Tetracladium setigerum (Grove) Ingold & & 2.9 & & & 9.2 \\
\hline Triscelophorus konajensis K.R. Sridhar \& Kaver. & & & $(0.4)$ & $(4)$ & \\
\hline Campylospora filicladia Nawawi & & & & 44.2 & \\
\hline Triscelophorus monosporus Ingold & $(26.2)$ & & & & \\
\hline Tripospermum myrti (Lind) S. Hughes & & 2.9 & & & \\
\hline Unidentified (Tricladium-like conidia) & & 2.9 & & & \\
\hline Total species & 5 & 6 & 2 & 4 & 5 \\
& $(3)$ & $(2)$ & $(3)$ & $(2)$ & $(1)$ \\
\hline Shannon diversity & 2.215 & 1.216 & 0.824 & 1.179 & 1.886 \\
\hline Pielou's equitability & $(1.198)$ & $(0.863)$ & $(0.060)$ & $(0.042)$ & \\
\hline & 0.954 & 0.470 & 0.824 & 0.589 & 0.812 \\
\hline
\end{tabular}

Table 3

Percentage contribution of water-borne hyphomycete species to conidial production and diversity in stemflow and throughfall (in parenthesis) of five tree species of Kaiga forest (Ah, Artocarpus heterophyllus; Cf, Cassia fistula; Fr, Ficus recemosa; Sc, Syzygium caryophyllatum; Xx, Xylia xylocarpa) (*new record to canopy)

\begin{tabular}{|l|c|c|c|c|c|}
\hline \multirow{2}{*}{ Taxon } & \multicolumn{5}{c|}{ Tree species } \\
\cline { 2 - 6 } & $\mathrm{Ah}$ & $\mathrm{Cf}$ & $\mathrm{Fr}$ & $\mathrm{Sc}$ & $\mathrm{Xx}$ \\
\hline Anguillospora crassa Ingold & 34 & 50 & & 16.7 & $(19.4)$ \\
& $(11.1)$ & $(100)$ & & & \\
\hline $\begin{array}{l}\text { Anguillospora longissima (Sacc. \& P. } \\
\text { Syd.) Ingold }\end{array}$ & $(3.3)$ & & $(28.6)$ & 16.7 & $\begin{array}{c}4.8 \\
(40)\end{array}$ \\
\hline Triscelophorus acuminatus Nawawi & $(53.3)$ & 50 & 14.3 & & $\begin{array}{c}4.8 \\
(7.5)\end{array}$ \\
\hline Lunulospora curuvla Ingold & $(3.3)$ & & & 33.3 & $\begin{array}{c}76.2 \\
(14.2)\end{array}$ \\
\hline Flagellospora curvula Ingold & & & 28.6 & $(20)$ & $\begin{array}{c}4.8 \\
\end{array}$ \\
\hline Ceratosporium cornutum Matsush. & 27.7 & & $(14.3)$ & & $(14.9)$ \\
\hline Triscelophorus monosporus Ingold & $(28.9)$ & & & 16.7 & 4.8 \\
\hline Helicomyces scandens Morgan & 6.4 & & & 16.7 & \\
\hline Trinacrium sp. & & & $(14.3)$ & & $(2.2)$ \\
\hline Flabellospora crassa Alas. & & & $(13.3)$ & & $(2.2)$ \\
\hline Dwayaangam sp. & & & 28.6 & & \\
\hline Unidentified (sickle-shaped conidia) & & & & & $(26.1)$ \\
\hline Dwayaangam cornuta Descals & & & & $(20)$ & \\
\hline Trisulcosporium acerinum H.J. Huds. \& B. Sutton & & & $(14.3)$ & & \\
\hline Flabellospora verticillata Alas. & & & $(14.3)$ & & \\
\hline Tricladium sp. & & & & & \\
\hline
\end{tabular}


Tab. 3. cont

\begin{tabular}{|l|c|c|c|c|c|}
\hline Helicomyces roesus Link & 12.8 & & & & \\
\hline *Hydrometrospora symmetrica J. Gönczöl \& Révay & 12.8 & & & & \\
\hline Flagellospora penicillioides Ingold & 6.4 & & & & \\
\hline Diplocladiella scalaroides G. Arnaud ex M.B. Ellis & & & & & 4.8 \\
\hline Clavatospora tentacula Sv. Nilsson & & & & & $(2.2)$ \\
\hline Alatospora acuminata Ingold & & & & & $(2.2)$ \\
\hline Triscelophorus konajensis K.R. Sridhar \& Kaver. & & & & & $(2.2)$ \\
\hline Total species & 6 & 2 & 4 & 5 & 6 \\
& $(5)$ & $(1)$ & $(6)$ & $(4)$ & $(12)$ \\
\hline Shannon diversity & 2.308 & 1.00 & 1.950 & 2.258 & 1.350 \\
& $(1.678)$ & & $(2.518)$ & $(1.922)$ & $(2.985)$ \\
\hline Pielou's equitability & 0.893 & 1.00 & 0.975 & 0.970 & 0.522 \\
& $(0.723)$ & & $(0.974)$ & $(0.961)$ & $(0.833)$ \\
\hline
\end{tabular}

trapped leaf litter of all tree species, while Triscelophorus acuminatus was more common in sediments of four tree species. Fungal diversity in trapped leaf litter as well as sediment of $A$. heterophyllus was higher than other tree species.

The species richness was higher in stemflow and throughfall than trapped leaf litter and sediments ( 23 vs. 13 species) (Tab. 3). Stemflow represented by 14 species ranging from 2 (Cassia fistula) to 6 (Artocarpus heterophyllus and Xylea xylocarpa). Throughfall consists of 16 species ranging from 1 (C. fistula) to 12 (X. xylocarpa). The conidial concentration in stemflow and throughfall was highest in $X$. xylocarpa and least in C. fistula (Fig. 1). Anguillospora crassa was common in stemflow of three out of five tree species, while Anguillospora longissima was seen in throughfall of four tree species. Fungal diversity was highest in throughfall of $X$. xylocarpa, while it was highest in trapped leaf litter in A. heterophyllus.

\section{DISCUSSION}

Water-borne hyphomycetes in tree canopies have been explored extensively in temperate regions than tropical regions. Niches in tree canopies investigated in temperate regions (mainly from Canada, Europe and Japan) were gymnosperm needles, angiosperm leaves, tree hole, honey dew, melting snow, stemflow and throughfall (e.g., Ando, Tubaki 1984; Czeczuga, Orłowska 1998a, 1998b; Magyar et al. 2005; Gönczöl, Révay 2003, 2004, 2006; Sokolski et al. 2006). Recently, a few niches in tree canopies (epiphytic fern, tree hole, stemflow and throughfall) of the west coast and Western Ghats of India have been studied (Sridhar et al. 2006; Sridhar, Karamchand 2009; Karamchand, Sridhar 2009).

The trapped leaf litter collected during summer consists of 10 species of waterborne hyphomycetes in our study. Such trapped leaf litter in tree holes and epiphytic fern in Sampaje of the Western Ghats during summer yielded 13 and 15 species (Karamchand, Sridhar 2008, 2009). However, conidial output from the trapped leaf litter in our study is considerably lower than Sampaje region (35-192 vs. 363-601/g). As colonized fungi are viable in trapped leaf litter even during dry season, they will be disseminated within or across the canopy and also to aquatic bodies. 

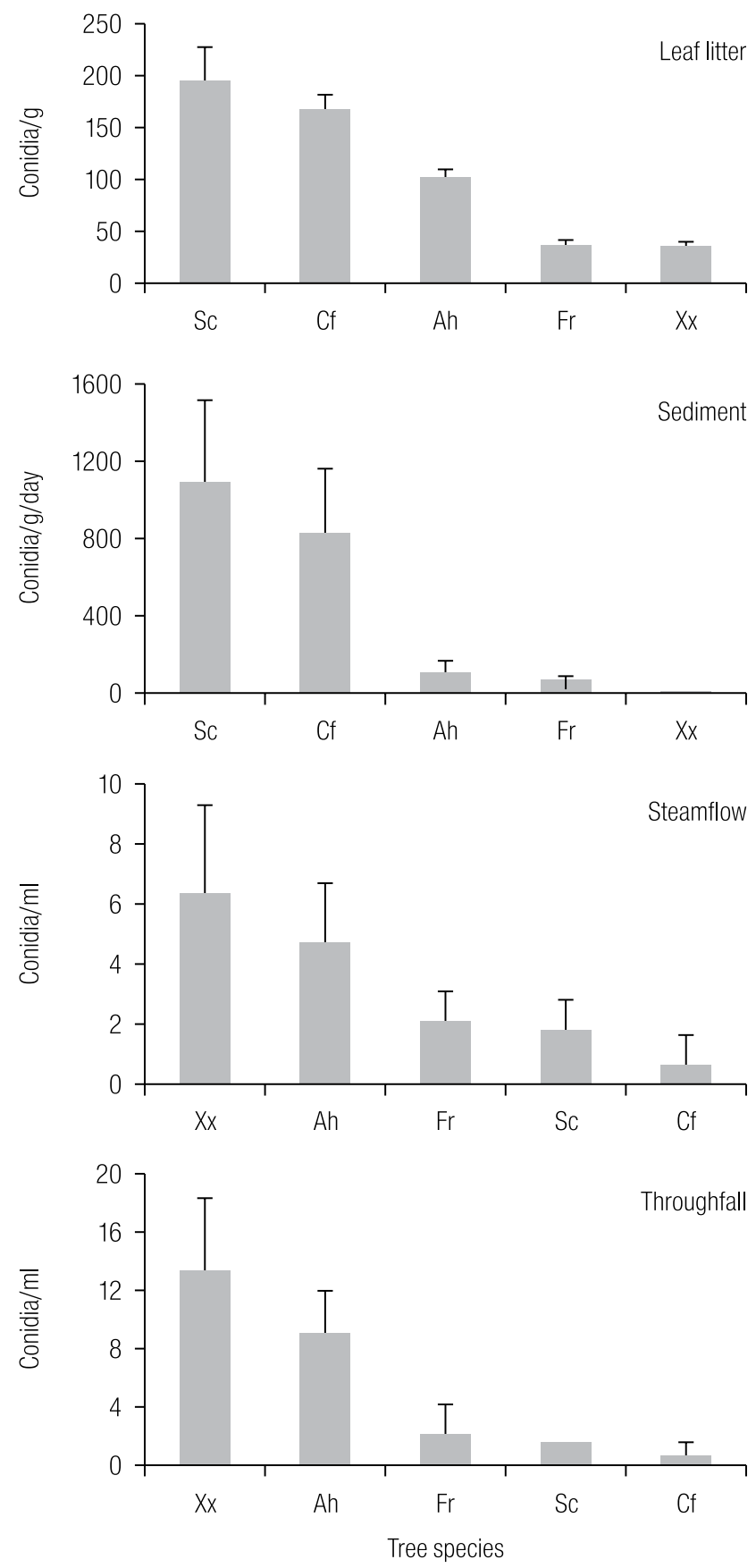

Fig. 1. Conidial output of water-borne hyphomycetes from trapped leaf litter, trapped sediment and conidial load in stemflow and throughfall of five tree species of Kaiga forest of the Western Ghats given in decreasing order $(n=3$, mean \pm SD) (Tree species: Ah, Artocarpus heterophyllus; Cf, Cassia fistula; Fr, Ficus recemosa; Sc, Syzygium caryophyllatum; Xx, Xylia xylocarpa). 
The sediment analysis employed in our study is an indirect method to evaluate viable propagules (either spores or mycelia) of water-borne hyphomycetes capable of colonizing baited sterile leaf disks (Sridhar et al. 2008). The species richness in sediments was lower than trapped leaf litter, stemflow and throughfall (6 vs. 10-16) reveals survival of a few species in tree sediments. Triscelophorus acuminatus was most common in sediments collected from four tree species. Similarly, T. acuminatus and T. konajensis were fairly dominant in sediments sampled from Kaiga region (Kaiga stream, Kali River and Kadra Dam) (K.R. Sridhar and N.M. Sudheep; unpublished observations) indicates their survival under low O-R potential. These species were also dominant in trapped leaf litter in tree holes of Sampaje region in spite of low dissolved oxygen in tree hole waters $(1.14 \mathrm{mg} / \mathrm{l})$ (Karamchand, Sridhar 2009). Anguillospora longissma, Flagellospora curvula, Lunulospora curvula, T. acuminatus and T. konajensis were highly colonized the leaf disks immersed in tree holes of Konaje region of the west coast of India in spite of low dissolved oxygen in tree hole waters (1.1-5.7 mg/l) (Karamchand 2008). Except for T. konajensis, rest of the species dominated in leaf litter or sediment, stemflow and throughfall in our study (see Tabs 2 and 3). Although the dissolved oxygen was low $(3.8 \mathrm{mg} / \mathrm{l})$ in a thermal spring of Southern India, 14 species of water-borne hyphomycetes were recovered by Chandrashekar et al. (1991). Survival of aquatic hyphomycetes up to 12 months under anaerobic conditions has been demonstrated by Field and Webster (1983). Depletion of oxygen from $94 \%$ to $4 \%$ saturation in microcosms resulted in $90 \%$ decrease in fungal biomass, the sporulation was strongly inhibited due to reduction of dissolved oxygen and the species richness was dropped to $60 \%$ (Medeiros et al. 2009). Viability of water-borne hyphomycetes in tree holes in spite of low dissolved oxygen during wet season and dry season facilitates recolonization of organic matter on the onset of wet conditions.

The $\mathrm{pH}$ of sediment collected from Xylia xylocarpa, Syzygium caryophyllatum and Artocarpus heterophyllus was acidic (4.8, 5.1 and 6.1). But the diversity of waterborne hyphomycetes was highest in $A$. heterophyllus and the leaf disks baited with sediment collected from $S$. caryophyllatum showed high conidial output. On the contrary, stemflow and throughfall of $X$. xylocarpa were alkaline $(8.5,8.7)$, but the species richness (6-12 species) and the Shannon's diversity (2.985) in throughfall were the highest among tree species studied. Bärlocher (1987) compared Canadian and European streams and demonstrated a slow or negligible decrease in species richness in circumneutral waters (5.7-7.2) with a rapid decline in alkaline waters (>7.2). Raviraja et al. (1998) supported this view by demonstrating a negative correlation between species richness vs. $\mathrm{pH}$ in Western Ghat streams. The species richness in throughfall and stemflow was higher than trapped leaf litter and sediment (14-16 vs. 6-10 species) corroborates earlier study on water-borne hyphomycetes in nonriparian tree species of the west coast of India (Sridhar, Karamchand 2009). The $\mathrm{pH}$ of tree hole waters in Sampaje region was close to neutral (6.98), while in our study, stemflow and throughfall were alkaline (7.2-8.5 and 7.3-8.7) (exception of throughfall of one tree species). The conidial concentration was highest in stemflow and throughfall of Xylia xylocarpa in spite of alkaline $\mathrm{pH}$ (8.5 and 8.7).

The conductivity was higher in sediment $(288 \mu \mathrm{S} / \mathrm{cm})$ as seen in tree hole waters of Sampaje (148 $\mu \mathrm{S} / \mathrm{cm})$ (Karamchand, Sridhar 2008). Compared to sediments and tree hole waters, the conductivity of stemflow and throughfall was low in our study 
(mean, 60-61 $\mu \mathrm{S} / \mathrm{cm}$ ) as evident in an earlier investigation $(10.1-72.9 \mu \mathrm{S} / \mathrm{cm}$ ) in the west coast (Sridhar, Karamchand 2009).

Three known and six unknown conidial morophotypes of Dwayaangam species have been reported in rainwater samples (15 out of 25 tree species) in different locations of Europe (Gönczöl, Révay 2006). Interestingly, Dwayaangam heterospora is known to parasitize eggs of rotifers and nematodes (Barron 1991). Dwayaangam colodena has also been reported as an endophyte in canopy needles of black spruce (Picea mariana) (Sokolski et al. 2006). In our study, Dwayaangam cornuta and Dwayaangam sp. contributed conidia between $26.1 \%$ (throughfall of Xylia xylocarpa) and $28.6 \%$ (stemflow of Ficus recemosa) respectively indicates their possible role as saprophytes, parasites and possibly endophytes in tree canopies.

The multiradiate conidial shape of aquatic hyphomycetes is the product of convergent evolutions and secondary adaptation to aquatic mode of life (Ingold 1975b; Belliveau, Bärlocher 2005). Stone et al. (1996) suggested that canopy fungi may be the early colonizers of tissues in intact leaves and twigs, and act as a link between soil and aquatic food webs by completing their life cycles. Studies on perfect-imperfect connections of aquatic hyphomycetes showed that the majority of species have evolved from ascomycetes found in decaying tree branches in streams (Webster, Descals 1979; Webster 1992; Marvanová 1997; Sivichai et al. 2002; Sivichai, Jones 2003) and molecular studies also confirmed their terrestrial relatives (Liew et al. 2002). Selosse et al. (2008) proposed a hypothesis that a large numbers of conidia of water-borne hyphomycetes congregate in stream foam disperse through wind or aerosols to tree canopies facilitating their survival as epiphytes, endophytes or saprophytes.

Our study supports the view that at least a few water-borne hyphomycetes survive in trapped leaf litter and sediments in tree canopies in viable state for a considerable period during dry season facilitating their perpetuation on the onset of wet season. Conidia in stemflow and throughfall during wet season are easily disseminated to other parts of the canopy or nearby aquatic habitats. Widespread occurrence of water-borne hyphomycetes in tree canopies and their adaptation to wide range of canopy ecological conditions in temperate and tropical regions suggests their life cycle alternates between aquatic and canopy habitats. Further studies are necessary to understand the functional significance of water-borne hyphomycetes, role in nutrient cycling in canopies and impacts of atmospheric pollution.

Acknowledgements. The authors are grateful to Mangalore University for permission to carry out this study at the Department of Biosciences and Nuclear Power Corporation of India Ltd. (NPCIL), Mumbai, India for financial support and award of research fellowship. Authors are thankful to Dr. H.M. Somashekarappa, University Science Instrumentation Centre, Mangalore University and Dr. P.M. Ravi, NPCIL, Kaiga, Karnataka for support. 


\section{REFERENCES}

Ando K., Tubaki K. 1984. Some undescribed hyphomycetes in the rain drops from intact leaf-surface. Transactions of the Mycological Society of Japan 25: 21-37.

APHA. 1995. Standard Methods in Examination of Water and Waste Water. American Public Health Association, USA.

Bärlocher F. 1987. Aquatic hyophomycete spora in 10 streams of New Brunswick and Nova Scotia. Canadian Journal of Botany 65: 76-79.

Barron G. L. 1991. A new species of Dwayaangam parasitic on eggs of rotifers and nematodes. Canadian Journal of Botany 69: 1402-1406.

Belliveau M. J.-R., Bärlocher F. 2005. Molecular evidence confirms multiple origins of aquatic hyphomycetes. Mycological Research 109: 1407-1417.

Carroll G. C., Carroll, F. E., Pike, L. H., Perkins, J. R., Sherwood M. 1980. Biomass and distribution patterns of conifer twig microepiphytes in a Douglas-fir forest. Canadian Journal of Botany 58: $624-630$.

Chandrashekar K. R., Sridhar K. R., Kaveriappa K. M. 1990. Periodicity of water-borne hyphomycetes in two streams of Western Ghat forests (India). Acta Hydrochimica et Hydrobiologica 18: 187-204.

Chandrashekar K. R. Sridhar K. R., Kaveriappa K. M. 1991. Aquatic hyphomycetes of a sulphur spring, India. Hydrobiologia 218: 151-156.

Czeczuga B., Orłowska M. 1997. Hyphomycetes fungi in rainwater falling from building roofs. Mycoscience 38: 447-450.

Czeczuga B., Orłowska M. 1998a. Hyphomycetes in rain water draining from intact trees. Roczniki Akademii Medycznej w Białymstoku 43: 66-84.

Czeczuga B., Orłowska M. 1998b. Hyphomycetes in the snow from gymnosperm trees. Roczniki Akademii Medycznej w Białymstoku 43: 85-94.

Czeczuga B., Orłowska M. 1999. Hyphomycetes in rainwater, melting snow and ice. Acta Mycol. 34: $181-200$.

Field J. I., Webster J. 1983. Anaerobic survival of aquatic fungi. Transactions of the British Mycological Society 81: 365-369.

Gönczöl J., Révay Á. 2003. Treehole fungal communities: aquatic, aero-aquatic and dematiaceous hyphomycetes. Fungal Diversity 12: 19-24.

Gönczöl J., Révay Á. 2004. Fungal spores in rainwater: stemflow, throughfall and gutter conidial assemblages. Fungal Diversity 16: 67-86.

Gönczöl J., Révay Á. 2006. Species diversity of rainborne hyphomycete conidia from living trees. Fungal Diversity 22: 37-54.

Gulis V., Marvanová L., Descals E. 2005. An illustrated key to the common temperate species of aquatic hyphomycetes. (In:) M. A. S. Graça, F. Bärlocher, M. O. Gessner (eds). Methods to Study Litter Decomposition: a Practical Guide. Springer, Dordrecht: 153-167.

Hedger J. 1990. Fungi in the tropical forest canopy. The Mycologist 4: 200-202.

Ingold C. T. 1975a. An Illustrated Guide to Aquatic and Water-Borne Hyphomycetes (Fungi Imperfecti) with Notes on their Biology. Freshwater Biological Association Scientific Publication \# 30, Ambleside, UK.

Ingold C. T. 1975b. Convergent evolution in aquatic fungi: the tetraradiate spore. Botanical Journal of Linnean Society 7: 1-25.

Karamchand K. S. 2008. Studies on Freshwater Filamentous Fungi of Western Ghats and West Coast of India. Ph.D. Thesis, Mangalore University, India.

Karamchand K. S., Sridhar K. R. 2008. Water-borne conidial fungi inhabiting tree holes of the west coast and Western Ghats of India. Czech Mycology 60: 63-74.

Karamchand K. S., Sridhar K. R. 2009. Association of water-borne conidial fungi with epiphytic tree fern (Drynaria quercifolia). Acta Mycol. 44 (1): 19-27.

Liew E. C. Y., Aptroot A., Hyde K. D. 2002. An evolution of the monophyly of Massarina based on ribosomal DNA sequences. Mycologia 94: 803-813.

Lodge D., Cantrell S. 1995. Fungal communities in wet tropical variation in time and space. Canadian Journal of Botany 73: 1391-1398.

Magurran A. E. 1988. Ecological Diversity and its Measurement. Princeton University Press, New Jersey. 
Magyar D., Gönczöl J., Révay Á., Grillenzoni F., Seijo-Coello M. D. C. 2005. Stauro- and scolecoconidia in floral and honeydew honeys. Fungal Diversity 20: 103-120.

Marvanová L. 1997. Freshwater hyphomycetes: a survey with remarks on tropical taxa. (In:) K. K. Janardhanan, C. Rajendran, K. Natarajan, D. L. Hawksworth (eds). Tropical Mycology. Science Publishers, New York: 169-226.

Medeiros A. O., Pascoal C., Graça M. A. S. 2009. Diversity and activity of aquatic fungi under low oxygen conditions. Freshwater Biology 54: 142-149.

Nadkarni, N. M., Mewin M. C., Niedert J. 2001. Forest canopies, plant diversity. (In:) Encyclopedia of Biodiversity, Volume 3, Academic Press, New York: 27-40.

Nawawi A. 1985. Aquatic hyphomycetes and other water-borne fungi from Malaysia. Malaysian Nature Journal 39: 75-134.

Pielou F. D. 1975. Ecological Diversity. Wiley InterScience, New York.

Rajashekhar M., Kaveriappa K. M. 2003. Diversity of aquatic hyphomycetes in the aquatic ecosystems of the Western Ghats of India. Hydrobiologia 501: 167-177.

Raviraja N. S., Sridhar K. R. and Bärlocher F. 1998. Fungal species richness in Western Ghat streams (Southern India; is it related to $\mathrm{pH}$, temperature or altitude? Fungal Diversity 1: 179-191.

Selosse M., Vohník M., Chauvet E. 2008. Out of the rivers: Are some aquatic hyphomycetes plant endophytes? New Phytologist 178: 3-7.

Shaw D. C. 2004. Vertical organization of canopy biota. (In:) M.D. Lowman, H.B. Rinker (eds). Forest Canopies. Elsevier Academic Press, London: 73-101.

Sivichai S., Jones E. B. G. 2003. Teleomorphic-anamorphic connections of freshwater fungi. (In:) C.K.M. Tsui, K. D. Hyde (eds). Freshwater Mycology. Fungal Diversity Series 10: 259-274.

Sivichai S., Jones E.B.G., Hywel-Jones N.L. 2002. Lignicolous freshwater higher fungi with reference to their teleomorph and anamorph stages. (In:) R. Watling, J. C. Frankland, A. M. Ainsworth, S. Isaac, C. H. Robinson (eds). Tropical Mycology. CAB International, UK, 41-49.

Sokolski S., Piché Y., Chauvet E., Bérubé J. A. 2006. A fungal endophyte of black spruce (Picea mariana) needles is also an aquatic hyphomycete. Molecular Ecology 15: 1955-1962.

Sridhar K. R. 2009. Fungi in the tree canopy - An appraisal. (In:) M. Rai, P. Bridge (eds). Applied Mycology. CAB International, UK: 73-91.

Sridhar K. R., Karamchand K. S. 2009. Diversity of water-borne fungi in throughfall and stemflow of tree canopies in India. Sydowia 61: 327-344.

Sridhar K. R., Kaveriappa K. M. 1989. Observations on aquatic hyphomycetes of the Western Ghat streams, India. Nova Hedwigia 49: 455-467.

Sridhar K. R., Chandrashekar K. R., Kaveriappa K. M. 1992. Research on the Indian subcontinent. (In:) F. Bärlocher (ed.). The Ecology of Aquatic Hyphomycetes. Springer-Verlag, Heidelberg: 182-211.

Sridhar K. R., Karamchand K. S., Bhat R. 2006. Arboreal water-borne hyphomycetes with oak-leaf basket fern Drynaria quercifolia. Sydowia 58: 309-320.

Sridhar K. R. Bärlocher F., Wennrich R., Krauss G.-J., Krauss G. 2008. Fungal biomass and diversity in sediments and on leaf litter in heavy metal contaminated waters of Central Germany. Fundamental and Applied Limnology 171: 63-74.

Stone J. F., Sherwood M. A., Carroll G. C. 1996. Canopy microfungi: function and diversity. Northwest Science 70: $37-45$.

Webster J. 1992. Anamorph-teleomorph relationships. (In:) F. Bärlocher (ed.). The Ecology of Aquatic Hyphomycetes. Springer-Verlag, Berlin: 99-117.

Webster J., Descals E. 1979. The teleomorphs of water-borne hyphomycetes from freshwater. (In:) B. Kendrick (ed.). The Whole Fungus. National Museums of Canada, Ottawa: 419-447. 